\title{
TINGKAT KEPATUHAN AYAH MEMBAYAR NAFKAH ANAK PASCA PERCERAIAN
}

\author{
Betra Sarianti \\ Fakultas Hukum Univesitas Muhammadiyah Bengkulu \\ betrasarianti1@gmail.com
}

\begin{abstract}
The purpose of this study was to determine and analyze the level of compliance of fathers paying the cost of living after a divorce. Non-doctrinal legal research that uses empirical legal research methods is to see the working of law in society. The results of the seven cases studied showed that the level of father's awareness of paying for a child is very low, even if there is a father providing a living after divorce, the value is not in accordance with the court's decision. Likewise, in the event of a divorce, the responsibility of giving a living shifts to who takes care of the child whether the father or mother, while others escape responsibility.
\end{abstract}

Keywords: Children; Law-compliance; Divorce.

Tujuan penelitian ini untuk mengetahui dan menganalisis tingkat kepatuhan ayah membayar biaya nafkah anak pasca perceraian. Penelitian hukum non doktrinal yang menggunakan metode penelitian hukum empiris yaitu melihat bekerjanya hukum dalam masyarakat. Hasil penelitian dari tujuh kasus yang diteliti menunjukan tingkat kesadaran ayah membayar nafkah anak sangat rendah kalaupun ada ayah memberi nafkah pasca perceraian nilainya tidak sesuai dengan putusan pengadilan. Demikian pula jika terjadi perceraian tanggung jawab memberi nafkah beralih kepada siapa yang memelihara anak apakah ayah atau ibu, sementara yang lain lepas tanggung jawab.

Kata Kunci: Anak; Kepatuhan-hukum; Perceraian.

\section{PENDAHULUAN}

Angka perceraian setiap tahun selalu meningkat di Indonesia. Berdasarkan data Badan Pusat Statistik (BPS) di tahun 2013 angka perceraian mencapai 324.247 perceraian, tahun 2014 meningkat menjadi 344.237 sedangkan ditahun 2015 angka perceraian berjumlah 347.256 kasus (www.bps.go.id). Sedangkan di tahun 2016 angka perceraian sudah mencapai 350.000 kasus. ${ }^{1}$

Pihak yang menjadi korban akibat perceraian orang tua adalah anak. Akibat perceraian orang tua dapat mempengaruhi prilaku anak seperti prilaku anti social, penurunan kinerja sekolah, kwalitas kesehatan rendah, rendah diri, putus sekolah dan sikap negatif kepada keluarga. ${ }^{2}$ Perceraian dapat dikatakan

1 Republika, Kasus Anak Korban Perceraian tinggi, diunduh 17-11-2017 dari https://www.republika.co.id/berita/koran/halaman-1/16/10/07/oeo5ft47kasus-anak-korban-perceraian-tinggi

2 Didmus Dewa, The Plight of Children as Secondary Victims of Divorce in Gweru Zimbabwe: 2013 - 2016, International Journal of Advanced Science and Technology, ISSN: 2005-4238 IJAST Copyright (c) 2016 SERSC, Vol.91, 2016, p. 
merupakan malapetaka bagi anak tetapi apabila terjadi maka malapetaka tersebut perlu diusahakan agar tidak menimbulkan malapetaka lain yang lebih berat bahayanya. ${ }^{3}$ Hal itu disebabkan karena anak adalah bagian yang tidak terpisahkan dari keberlangsungan hidup manusia dan keberlangsungan sebuah bangsa dan Negara. agar kelak mampu bertanggung jawab dalam keberlangsungan bangsa dan Negara, setiap anak perlu mendapat perlindungan dan kesempatan seluas luasnya untuk tumbuh dan berkembang secara optimal baik fisik, mental, maupun social. Untuk itu perlu dilakukan upaya perlindungan untuk mewujutkan kesejahteraan anak dengan memberikan jaminan terhadap hak haknya tanpa adanya perlakuan diskriminasi. ${ }^{4}$

Disamping itu Islam menjunjung tinggi hak hak anak. Orang tua selayaknya memberikan hak haknya dengan baik dan itu merupakan tanggug jawab atau kewajiban yang harus ditegakan demi perkembangan anak anaknya dengan baik. Anak merupakan amanah yang dititipkan Allah SWT. Oleh karenanya, orang tua harus dengan jerih payah menjaganya dan menyelamatkan dari hal hal yang kurang atau tidak nyamannya anak dalam menggapai kehidupan untuk menuju kehidupan yang lebih baik. ${ }^{5}$

Seperti halnya perkawinaan, perceraian orang tua mempunyai akibat hukum terhadap anak hasil dari perkawinan, baik ayah atau ibu tetap berkewajiban memelihara dan mendidik anak anaknya, semata-mata berdasarkan kepentingan anak, bilamana terjadi perselisihan mengenai penguasaan anakanak, Pengadilan memberikan keputusannya. Jadi ayah yang bertanggung jawab atas semua biaya pemeliharaan dan pendidikan yang diperlukan anak. Bilamana ayah kenyataanya tidak dapat memberi kewajiban tersebut maka Pengadilan dapat menentukan bahwa ibu ikut memikul biaya tersebut ${ }^{6}$

Realitas ditengah masyarakat, banyak anak anak korban perceraian tidak mendapatkan hak hak sebagai anak dari orang tua yang bercerai. Berdasarkan persepsi anak terhadap komunikasi orang tua yang bercerai, lebih dari $49 \%$ orang tua yang bercerai putus komunikasi satu sama lain, sedangkan 47\% anak menyatakan komunikasi baik dan hanya 3,5\% anak yang merasakan komunikasi orang tua mereka sangat baik setelah bercerai. Data tersebut menunjukan fakta hampir $50 \%$ orang tua yang bercerai tidak lagi berhubungan satu sama lain

12

3 Rahmadi Indra Tektona, Kepastian Hukum Terhadap Perlindungan Hak Anak Korban Perceraian, Jurnal Muwazah, 2502-5368 (Paper) ISSN 2085-8353 Volume. 4, Nomor. 1, 2012, p. 44

4 Betra Sarianti, Perlindungan Anak Berhadapan Dengan Hukum Diantara Harapan dan Hambatan, Jurnal Ilmiah Kutei ,ISSN 1412-9639 edisi 28 April 2015.

5 Anisa Indrayani, Pendidikan Anak Dalam Keluarga Sebagai Bentuk Perlindungan Anak Dalam Perspektif Al-Qur'an, Jurnal Musawa ISSN: 1412-3460 E-ISSN: 2503-4596; Vol.10, No.2, Juli 2011, p.184.

6 Mardani, Hukum Keluarga Islam di Indonesia, Jakarta, Prenamedia Group, 2016, hlm. 130 . 
sehingga anak tidak dapat lagi mendapatkan hak haknya sebagai anak dari orang tua secara penuh. ${ }^{7}$

Disamping itu meskipun ada putusan pengadilan agama yang telah memutuskan besaran nafkah anak yang harus dibayar tergugat (ayah) setiap bulan, sebahagian besar dari putusan tersebut tidak dipatuhi oleh tergugat. Kalaupun ada yang dipatuhi akan tetapi besaranya tidak sesuai dengan yang diputuskan oleh pengadilan. Apalagi jika si ayah sudah menikah dan sibuk dengan keluarga baru. Kewajiban memberikan nafkah pada anak pasca perceraian semakin tidak dipatuhi. Akhirnya tinggalah si ibu membanting tulang menafkahi anak. ${ }^{8}$ Dalam UndangUndang Dasar Negara RI 1945 mengenai hak atas anak yang termuat dalam Pasal 28 B ayat 2 berbunyi: "Setiap anak berhak atas kelangsungan hidup, tumbuh kembang, serta berhak atas perlindungan dari kekerasan dan diskriminasi”. Jaminan perlindungan dan pemenuhan hak anak ini ditandai dalam UUD 1945 dan beberapa ketentuan peraturan perundangundangan baik yang bersifat nasional maupun internasional. Jaminan ini dikuatkan melalui ratifikasi konvensi internasional tentang hak anak, yaitu pengesahan Konvensi Hak Anak melalui Keputusan Presiden Nomor 36 tahun 1990 tentang Pengesahan Convention On The Rights Of The Child (Konvensi Tentang Hak Hak Anak).

Mengacu pada ketentuan hukum yang menjamin hak anak dikaitkan dengan persoalan perceraian orang tua sebagaimana yang telah diuraikan, maka penelitian hukum bertujuan untuk mengkaji masalah tingkat kesadaran orang tua terutama ayah dalam memberikan nafkah anak pasca perceraian di Kota Bengkulu.

\section{METODE PENELITIAN}

Penelitian ini merupakan penelitian hukum empiris, yang lebih memfokuskan kepada gejala masyarakat sebagai suatu institusi social. ${ }^{9}$ Penelitian ini menggunakan data primer dan data sekunder. Data primer merupakan bahan penelitian yang berupa fakta-fakta empiris sebagai perilaku maupun hasil perilaku manusia. Baik dalam bentuk perilaku verbal perilaku nyata, maupun perilaku yang terdorong dalam barbagai hasil perilaku

7 Ardiana Mali Anglisticum, Parents Communication after Divorce and Its Impact on their Children Behavior, Journal (IJLLIS) p-ISSN: 1857-8179 e-ISSN: 1857-8187 Volume 4, issue 11, 2015.

8 A.Choiri, Penjaminan Harta Ayah Terhadap Kelalaian Pembayaran Nafkah Anak Pasca Perceraian (Perlindungan Hukum Terhadap Anak Korban Perceraian Bagian 2), diakses tanggal 02 Juli 2018 dari https://badilag.mahkamahagung.go.id/artikel/publikasi/artikel/penjaminanharta-ayah-terhadap-kelalaian-pembayaran-nafkah-anak-pasca-perceraian-olehdr-h-a-choiri-sh-mh-28-10, 28 Oktober 2015.

9 Anton F.Susanto, Penelitian Hukum Transformatif Partisipatoris, Malang, Setara Press, 2015, hlm. 17. 
atau catatan-catatan/arsip. Data primer diperoleh secara langsung dari lokasi penelitian yaitu dengan cara wawancara langsung dan observasi atau pengamatan secara langsung dilapangan. Data sekunder merupakan bahan hukum dalam penelitian yang diambil dari studi kepustakaan yang terdiri dari bahan hukum primer, bahan hukum sekunder dan bahan non hukum. ${ }^{10}$ Data sekunder diperoleh dengan studi dokumentasi dan penelusuran literatur yang berkaitan dengan penegakkan hukum pidana dan teori yang mendukungnya, dimana data sekunder ini terdiri dari (1) Bahan hukum primer yaitu bahan hukum yang bersifat autoritatif artinya memiliki suatu autoritas mutlak dan mengikat. Berupa ketentuan hukum yang mengikat seperti, peraturan perundang-undangan, catatan resmi dan lain-lain yang berkaitan dengan penegakkan hukum pidana; (2) Bahan hukum sekunder yaitu bahan hukum yang memberikan penjelasan terhadap/mengenai bahan hukum primer. Seperti doktrin, jurnal, karya ilmiah dibidang hukum dan lain-lain; (3)Bahan hukum tersier adalah bahan hukum yang relevan seperti kamus hukum, ensiklopedia dan kamus hukum lain yang masih relevan.

Penelitian ini dilakukan di Pegadilan Agama Bengkulu yang beralamat di Jl. Basuki Rahmat No.11 Belakang Padang Kota Bengkulu 38222, Lembaga Konsultasi Dan Bantuan Hukum Universitas Bengkulu (LKBH UMB) beralamat di Jl. Salak Raya Padang Nangka Kota. Tehnik Pengumpulan Data mempergunakan teknik random yang didasarkan atas purposive sampling, maka dari populasi tersebut dipilih beberapa pihak yang dijadikan sebagai sampel dan dianggap dapat mewakili. Selain melakukan wawancara dengan sample yang telah ditentukan, data juga dikumpulkan melalui penelitian kepustakaan dan wawancara dengan beberapa narasumber dilingkungan Pengadilan Agama Bengkulu dan LKBH UMB. Sedangkan untuk data sekunder diperoleh dengan studi kepustakaan yaitu pengumpulan data melalui literatur dan dokumen lain yang berkaitan dengan permasalahan. Selanjutnya data-data tersebut dianalisis secara kualitatif, dan disajikan dalam bentuk deskriptif berupa kata kata lisan atau tulisan tentang tingkah laku manusia yang dapat diamati. Data Kualitatif dapat dipilah menjadi tiga jenis yaitu pertama; hasil pengamatan, kedua hasil pembicaraan; ketiga hasil tertulis. ${ }^{11}$

\section{HASIL DAN PEMBAHASAN}

\section{Tingkat Kesadaran Orang Tua (Ayah) Untuk Tetap Menafkahi Anak Anak Pasca Bercerai Di Kota Bengkulu.}

Angka perceraian cendrung meningkat dari tahun ke tahun di Kota Bengkulu. Pada tahun 2016 jumlah perkara yang terdaftar di Pengadilan Agama

10

11 Ivanovich Agusta, Teknik Pengumpulan dan Analisis Data Kualitatif, Makalah disampaikan dalam pelatihan metode kualitatif di pusat Penelitian Sosial Ekonomi. Litbang Pertanian Bogor 27 Februari 2003 
Bengkulu sejumlah 856 perkara. Dari jumlah tersebut 773 adalah perkara perceraian baik perkara Cerai Talak maupun Cerai Gugat. Sedangkan Tahun 2017 jumlah perkara yang terdaftar sejumlah 973 perkara, 885 adalah perkara perceraian baik itu Cerai Talak maupun Cerai Gugat. Sementara di tahun 2018 ini sampai bulan Mei perkara yang terdaftar di Pengadilan Agama Bengkulu sejumlah 460 perkara, 425 adalah perkara perceraian. Untuk lebih jelasnya dapat dilihat tabel 1 sebagai berikut :

Tabel 1.

Jumlah Perkara Perceraian di Pengadian Agama Bengkulu

Tahun 2016 - 2018

\begin{tabular}{|lllll|}
\hline \multirow{3}{*}{ No } & Jenis Perkara & \multicolumn{3}{c|}{ TAHUN } \\
1. & & 2016 & 2017 & 2018 (Mei 2018) \\
2. & Cerai Talak & 225 & 245 & \\
& Cerai Gugat & 548 & 610 & \\
& Jumlah & 773 & 855 & 425 \\
\hline
\end{tabular}

Sumber : Pengadilan Agama Bengkulu.

Dari data tersebut dapat dilihat angka perceraian sangat tinggi di Kota Bengkulu, dimana setiap tahun angka tersebut cendrung meningkat bahkan ditahun 2018 pada bulan Mei ini sudah terdaftar 425 perkara perceraian.

Menurut data pada Pusat Konsultasi dan Bantuan Hukum (Posbakum) Aisyiyah, sebagai lembaga pemberi layanan bantuan hukum di Pengadilan Agama Bengkulu tahun 2017 menyebutkan ada beberapa alasan yang menjadi penyebab terjadinya perceraian seperti masalah kekerasan dalam rumah tangga, meninggalkan tempat kediaman bersama, nafkah, berselingkuh/menikah siri, pemadat, tidak jujur masalah keuangan, tidak peduli atau mementingkan diri sendiri, sering pergi tanpa izin, hubungan dengan keluarga besar tidak harmonis, campur angan keluarga, dan cemburu buta.

Penyebab perceraian tidak bisa tunggal, akan tetapi saling berkaitan antara beberapa penyebab seperti faktor kekerasan rumah tangga berkaitan dengan faktor ekonomi atau faktor nafkah berkaitan dengan mementingkan diri sendiri atau tidak jujur masalah keuangan. Dimana dalam gugatan cerai gugat atau permohon cerai talak alasan alasan perceraian akan dicantumkan dalam posita permohonan atau gugatan.

Perkara perceraian yang mencantumkan nafkah anak biasanya terdapat dalam perkara cerai talak, dimana suami berkedudukan sebagai pemohon yang mengajukan perkara ke pengadilan sedangkan istri berkedudukan sebagai termohon. Dalam perkara cerai talak ini jika istri datang memenuhi panggilan pengadilan untuk bersidang, biasanya akan mengajukan gugat balik (rekonvensi). Diantara gugatan rekonvensi yang diajukan salah satunya adalah meminta biaya hadhanah (nafkah anak). Pengadilan Agama mengabulkan besaran nafkah anak berdasarkan besaran penghasilan Pemohon.

Disamping perkara cerai talak yang mencantumkan nafkah anak dalam putusan hakim. Dalam perkara cerat gugat dimana istri berkududukan sebagai 
Penggugat yang mengajukan gugatan ke pengadilan, sedangkan suami berkedudukan sebagai Tergugat. Dalam gugatannya istri juga mencantumkan nafkah anak dalam gugatan, dan jika gugatan tersebut beralasan hukum untuk diterima maka hakim akan mengabulkan gugatan tersebut. Akan tetapi sungguhpun pengadilan telah memutuskan bersaran kewajiban nafkah anak yang harus dibayar oleh Pemohon/Tergugat, tetap saja putusan tersebut tidak di patuhi oleh Pemohon/Tergugat.

Sebagai contoh Putusan Nomor 0402/PDT.G/2015.PA.BN tanggal 15 Februari 2016, dimana Pemohon yang berkedudukan sebagai PNS mengajukan permohonan Cerai Talak ke kepada Termohon pekerjaan Ibu Rumah Tangga di Pengadilan Agama Bengkulu dengan alasan : ,"Termohon tidak patuh kepada Pemohon, Termohon sering berhutang tanpa sepengetahuan Pemohon." Pada waktu pemeriksaan di pengadilan, Termohon mengajukan Gugatan Rekonvensi salah satu petitumnya berbunyi :" Menetapkan secara hukum bahwa biaya hadlanah (nafkah anak) masing masing Bintang (nama samaran) (13 tahun 10 bulan), Bulan (nama samaran) (9,5 tahun) dan Matahari (nama samaran) (1 tahun 9 bulan ) dibebankan kepada Pemohon konvensi/Tergugat rekonvensi sebesar Rp 750.000,-(tujuh ratus lima puluh ribu rupiah) per bulan peranak terhitung sejak perkara ini diputus oleh Pengadilan Agama Bengkulu dan mempunyai kekuatan hukum tetap hingga anak tersebut dewasa atau mandiri.

Pengadilan Agama Bengkulu dalam putusannya mengabulkan sebagai Gugatan Rekonvensi yang amarnya berbunyi: “ Menetapkan nafkah untuk biaya (hadhanah)dua orang anak yang berada dalam asuhan (hadhanah) Penggugat Rekonvensi (selaku ibu kandung) yang harus dibayar Tergugat Rekonvensi (selaku ayah kandung) setiap bulan sekurang kurangnya sebesar Rp.1.000.000,- (satu juta rupiah) sampai anak tersebut dewasa (umur 21 tahun) atau mandiri."

Setelah orang tua berpisah Bintang tinggal dengan ayahnya sedangkan Bulan dan Matahari tinggal dengan Ibunya. Berdasarkan putusan pengadilan meskipun kedua anak tinggal dengan ibunya si ayah tetap berkewajiban memberikan nafkah sebesar satu juta perbulan, akan tetapi dalam kenyataannya ayah kandung dari kedua anak yang tinggal dengan ibunya tersebut tidak dinafkahi oleh ayah mereka setelah bercerai.

Kasus kedua adalah Perkara Nomor 0519/PDT.G/2016/PA.BN tanggal 13 Oktober 2016. Dimana Pemohon mengajukan permohonan Cerai Talak kepada istrinya dengan alasan:" Termohon tidak bisa mengatur keuangan keluarga, Termohon tidak patuh kepada Pemohon. Dalam pemeriksaan persidangan istri (Termohon) hadir dan mengajukan Gugatan Rekonvensi dimana salah satu petitumnya berbunyi : "Memberikan biaya hadhanah untuk 2 (dua) orang anak sampai mereka dewasa atau mandiri sebesar Rp. 750.000,- (tujuh ratus lima puluh ribu rupiah) perbulan peranak," . Atas gugatan Rekonvensi tersebut majelis hakim Pengadilam Agama Bengkulu mengabulkan sebagian gugatan Penggugat Rekonvensi dengan menjatuhkan putusan," Menetapkan nafkah untuk biaya 
(hadhanah)dua orang anak yang berada dalam asuhan (hadhanah) Penggugat Rekonvensi (selaku ibu kandung) yang harus dibayar Tergugat Rekonvensi (selaku ayah kandung) setiap bulan sekurang kurangnya sebesar Rp.1.000.000,- (satu juta rupiah) sampai anak tersebut dewasa (umur 21 tahun) atau mandiri."

Setelah perkara tersebut diputuskan pengadilan, apa yang menjadi kewajiban ayah memberi nafkah kepada anak anaknya meskipun telah bercerai tidak dipatuhi oleh mantan suami walaupun telah berbagai cara ditempuh oleh pihak istri diantaranya melaporkan mantan suami kepada atasan tempat suami bekerja, hanya beberapa bulan dipatuhi setelah itu kembali seperti semula. Kalaupun mantan suami memberikan uang kepada anak anak setelah perceraian itu hanya berupa uang jajan yang diberikan jika bertemu. Tidak ada kesadaraan akan tanggung jawab memberi nafkah oleh suami sebagaimana ketika mereka masih suami istri.

Selain dua kasus di atas yang mencantumkan biaya hadhanah Anak dalam putusan pengadilan, banyak putusan perkara perceraian yang tidak memutuskan biaya hadhanah. Putusan tersebut terdapat dalam perkara Cerai Gugat yang diajukan istri, seperti perkara Nomor : 0126/PDT.G/2016/PA.BN tanggal 10 Mei 2016 antara Bunga (nama samaran) sebagai Penggugat mengajukan Cerai Gugat terhadap suaminya Bujang (nama samaran) dimana alasan gugatan adalah Tergugat telah berselingkuh dan menikah siri dengan selingkuhannya. Dalam gugatan tersebut Penggugat tidak mencantumkan biaya hadhanah anak, sehingga amar putusan hakim tidak memutuskan biaya hadhanah. Setelah terjadi perceraian ayah (Bujang) tidak pernah lagi menafkahi anak anaknya, malah yang dinafkahi Bujang adalah anak bawaan dari istri sirinya, sementara anak kandung tidak pernah diberi nafkah.

Dalam prakteknya ada atau tidak ada putusan hakim mengenai biaya hadhanah anak, suami tetap tidak memberikan nafkah anak yang merupakan kewajibannya pasca perceraianan. Kalaupun memberi hanya sesekali jika bertemu dengan anak. Malah mantan suami bunga menafkahi anak dengan istri sirinya, sementara anak kandung tidak diberi nafkah. Untuk lebih jelasnya dapat dilihat dari tabel 2 berikut ini :

Tabel 2

Tingkat Kepatuhan Ayah Membayar Nafkah Anak Pasca Perceraian

\begin{tabular}{|c|c|c|c|}
\hline No & Jenis Perkara & $\begin{array}{l}\text { Besaran Nafkah } \\
\text { Anak Berdasarkan } \\
\text { Putusan Pengadilan }\end{array}$ & $\begin{array}{l}\text { Realiasi } \\
\text { Pembayaran } \\
\text { Nafkah Anak } \\
\end{array}$ \\
\hline 1. & $\begin{array}{l}\text { Perkara Cerai Talak } \\
\text { dengan Nomor } \\
\text { Putusan } \\
\text { 0402/PDT.G/2015. } \\
\text { PA.BN tanggal } 15 \\
\text { Februari 2016 }\end{array}$ & $\begin{array}{l}\text { Rp.1.000.000,- } \\
\text { untuk dua orang } \\
\text { anak, karena satu } \\
\text { anak dipelihara } \\
\text { oleh Pemohon. }\end{array}$ & $\begin{array}{l}\text { Tidak pernah } \\
\text { dibayarkan, } \\
\text { kalaupun } \\
\text { hanya ada } \\
\text { uang jajan yang } \\
\text { diberikan }\end{array}$ \\
\hline
\end{tabular}


Supremasi Hukum : Jurnal Penelitian Hukum

p-ISSN: 1693-766X ; e-ISSN: 2579-4663, Vol. 27, No. 2, Agustus 2018, 105-117

\begin{tabular}{|c|c|c|c|}
\hline & & & bertemu. \\
\hline 2. & $\begin{array}{l}\text { Perkara Cerai Talak } \\
\text { Nomor Putusan } \\
\text { 0519/PDT.G/2016/ } \\
\text { PA.BN tanggal } 13 \\
\text { Oktober 2016. }\end{array}$ & $\begin{array}{l}\text { Rp. } 1.000 .000,- \\
\text { perbulan }\end{array}$ & $\begin{array}{lr}\text { Tidak dipatuhi } \\
\text { sesuai putusan } \\
\text { pengadilan. } \\
\text { Berbagai cara } \\
\text { telah dilakukan } \\
\text { istri termasuk } \\
\text { melaporkan } \\
\text { kepada atasan } \\
\text { mantan suami } \\
\text { hanya sebentar } \\
\text { dipatuhi setelah } \\
\text { itu suami kembali } \\
\text { melalaikan } \\
\text { kewajibannya }\end{array}$ \\
\hline 3 & $\begin{array}{l}\text { Perkara } \begin{array}{r}\text { Cerai } \\
\text { Gugat dengan }\end{array} \\
\text { Putusan Nomor : } \\
\text { 0126/PDT.G/2016/ } \\
\text { PA.BN tanggal } 10 \\
\text { Mei 2016 }\end{array}$ & $\begin{array}{l}\text { Tidak dicantumkan } \\
\text { besaran nafkah } \\
\text { anak dalam } \\
\text { putusan pengadilan } \\
\text { karena Penggugat } \\
\text { tidak } \\
\text { mencantumkan } \\
\text { nafkah anak dalam } \\
\text { surat gugatannya. }\end{array}$ & $\begin{array}{lr}\text { Tidak } & \text { pernah } \\
\text { memberi } & \text { nafkah } \\
\text { kepada } & \text { anak } \\
\text { pasca perceraian. } & \text { Malah } \\
\text { dinafkahi yang } \\
\text { bawaan dari istri } \\
\text { sirinya. }\end{array}$ \\
\hline
\end{tabular}

Dari ketiga kasus tersebut di atas dapat dilihat tingkat kepatuhan orang tua dalam hal ini ayah dalam memberikan nafkah Anak setelah perceraian sangat rendah. Besaran nafkah yang sudah ditetapkan pengadilan tidak dipatuhi apalagi putusan pengadilan yang hanya mengabulkan gugatan perceraian. Sehingga jika terjadi perceraian Anaklah yang menjadi pihak yang menjadi korban karena tidak lagi mendapatkan apa yang menjadi haknya sebagai anak.

Selain data yang diperoleh di Pengadilan Agama Bengkulu, data lain tentang tingkat kepatuhan ayah membayar nafkah anak didapat dari hasil pertemuan antara penggiat perlindungan perempuan dan anak dari lembaga Koalisi Perempuan Indonesia (KPI) dengan Lembaga Konsultasi dan Bantuan Hukum Universitas Muhamadiyah Bengkulu yang dilakukan pada bulan Juli 2018 diperoleh fakta dimana ayah yang tidak menafkahi anak pasca perceraian berdampak terhadap anak baik secara psikologis, ekonomi dan hak hak anak untuk mendapatkan pendidikan sebagai berikut : "Ibu Neneng telah bercerai dengan suaminya berinisial HR tahun 2016 di Pegadilan Agama Bengkulu, dimana dalam putusan Pengadilan Agama Bengkulu telah menetapkan besaran nafkah anak yang harus dibayar oleh HR, sedangkan HR bekerja sebagai ASN. Setelah bercerai ketiga Anak tinggal dengan Ibu Neneng, dimana ketiga anak 
Supremasi Hukum : Jurnal Penelitian Hukum

p-ISSN: 1693-766X ; e-ISSN: 2579-4663, Vol. 27, No. 2, Agustus 2018, 105-117

tersebut adalah; Kembar A umur 16 tahun, Kembar B umur 16 tahun, dan Ganteng umur 7 tahun”.

Pasca perceraian, jalinan komunikasi antara anak dan ayah tidak terjalin dengan baik, selayaknya anak pada umumnya yang masih membutuhkan kasih sayang dan perhatian serta kebutuhan atas tumbuh kembang anak, bahkan HR jarang sekali melihat anak-anaknya, begitu juga dengan hak anak dan isteri atas uang nafkah tidak maksimal diberikan untuk kebutuhan sehari-hari juga kebutuhan sekolah dari tiga (3) orang anaknya.

Atas perceraian orang tua berdampak kepada ketiga anak bu Neneng baik secara psikis maupun ekonomi. Secara psikis, anak-anak lebih banyak diam, sensitive dan jarang bergaul dengan teman-teman sebayanya. Sedangkan secara ekonomi, kebutuhan anak-anak korban banyak tidak terpenuhi apa lagi kedua anak korban yang kembar sudah duduk di kelas 2 SMA sudah banyak sekali yang seharusnya mereka miliki atau kerjakan, seperti : les, kursus, praktek dll, karena kondisi keterbatasan ekonomi sang ibu, tak semua hal yang mereka dapatkan.

"Ibu Puspa bercerai tahun 2016 dengan suamiya berinisial DM pekerjaan pemborong. Adapun alasan perceraian adalah suami berselingkuh dan menikah dengan selingkuhannya. Pasca perceraian di Pengadilan Agama, Ibu Puspa dan anaknya pulang kerumah orang tua korban, karena harus pemulihan sakit yang diderita korban yaitu terkena luka bakar akibat tersiram air panas. Setelah tidak serumah lagi DM tidak pernah berkomunikasi dan tidak pernah memberi nafkah pada anak".

Dampak yang dialami Anak akibat perceraian secara psikis, anak korban lebih banyak diam, murung dan suka mengamuk jika ada sesuatu yang ia inginkan. Secara sosial, anak korban lebih minder dari teman-teman sepermainannya secara ekonomi, kebutuhan anak korban banyak tidak terpenuhi karena ibu korban yang sehari-harinya hanya sebagai pekerja buruh serabutan. Kasus sebagai berikut:

"Ibu Jurai umur 40 tahun pekerjaan serabutan telah bercerai dari suaminya UJ umur 45 tahun pekerjaan Swasta pada tahun 2015. Alasan perceraian adalah suami berselingkuh dan menikah dengan selingkuhannya,. Anak Anak korban berjumlah lima orang yang terdiri dari : M y(16 tahun ), Aby (14 tahun), Mr (12 tahun),Nr (11 tahun) Hd (7 tahun)”. Semenjak bercerai UJ tidak pernah lagi berkomunikasi dengan anak anaknya, tidak pernah mau tau keadaan anak anaknya dan tidak pernah memberi nafkah, untuk memenuhi kebutuhan sehari hari, Ibu Jurai bekerja apa saja dengan gaji 25 ribu sehari, sehingga anak laki lakinya yang lulus SD tidak sekolah lagi karena harus membantu ibunya bekerja.

Dampak yang dialami anak anak akibat perceraian orang tuanya adalah; Anak sulung korban (My) pasca lulus SD tidak sekolah lagi dan menikah di usia dini, Anak no 2 (Aby) lulus SD tidak sekolah lagi karena harus bekerja serabutan untuk membantu ibunya menafkahi adik-adiknya, sedangkan Anak no 3 (Rn) 
putus sekolah pada saat kelas 4 SD karena tidak ada uang untuk membeli kebutuhan yang tak terduga baik di sekolah juga diluar sekolah, Anak no 4 ( Nr) sekarang duduk di kelas 6 SD Anak no 5 (Hd) belum sekolah.

Secara Psikis, anak korban lebih banyak diam, murung dan suka ngamukngamuk jika ada sesuatu yang ia inginkan. Secara Sosial, anak korban lebih minder dari teman-teman sepermainannya . Secara Ekonomi, anak korban kebutuhan anak korban banyak tidak terpenuhi Secara Pendidikan ,anak-anak korban kehilangan hak pendidikanya. Seperti kasus berikut: "Ibu Marni telah bercerai dengan suaminya yang bernama BS pekerjaan swasta pada tahun 2016 . Setelah bercerai BS pulang ke Lampung dan meninggalkan 2 orang anak masig masing Yl (15 tahun) dan Fb (13 tahun) dengan ibu Marni. Sampai saat ini BS tidak diketahui keberadaannya dan tidak pernah mengirimkan nafkah untuk anak anaknya.Untuk memenuhi kebutuhan anaknya bu Marni bekerja serabutan".

Perceraian bu Marni berdampak terhadap anak anaknya yaitu secara psikis, anak korban lebih banyak diam, sensitive dan minder dari teman-teman sebayanya, secara ekonomi, anak korban yang sulung putus sekolah karena keterbatasan biaya, anak anak kehilangan hak untuk mendapatkan pendidikan yang layak. Karena masalah ekonomi anak bungsu bu Marni berurusan dengan aparat hukum karena mencuri disalah satu warung manisan milik warga karena pergaulan yang salah.

Untuk lebih jelasnya dapat dilihat tabel sebagai berikut:

Tabel 3 : Dampak Perceraian Pada Anak.

\begin{tabular}{|c|c|c|c|}
\hline $\mathrm{NO}$ & $\begin{array}{l}\text { KASUS } \\
\text { PERCERAIAN }\end{array}$ & $\begin{array}{l}\text { PEMBERIAN NAFKAH } \\
\text { PASCA PERCERAIAN }\end{array}$ & DAMPAK PADA ANAK \\
\hline 1 & Neneng dan HR & $\begin{array}{l}\text { Sangat kurang tidak } \\
\text { sesuai } \quad \text { dengan } \\
\text { besaran nafkah } \\
\text { hadlanah yang telah } \\
\text { diputuskan } \\
\text { Pengadilan Agama }\end{array}$ & $\begin{array}{l}\text { Secara psikis, anak- } \\
\text { anak lebih banyak } \\
\text { diam, sensitive dan } \\
\text { jarang bergaul dengan } \\
\text { teman-teman } \\
\text { sebayanya. Sedangkan } \\
\text { secara ekonomi, } \\
\text { kebutuhan anak-anak } \\
\text { korban banyak tidak } \\
\text { terpenuhi }\end{array}$ \\
\hline 2 & Puspa dan DM & $\begin{array}{l}\text { Setelah bercerai tidak } \\
\text { ada komunikasi dan } \\
\text { tidak } \quad \text { pernah } \\
\text { memberi } \quad \text { nafkah } \\
\text { kepada anak }\end{array}$ & $\begin{array}{l}\text { secara psikis, anak } \\
\text { korban lebih banyak } \\
\text { diam, murung dan } \\
\text { suka mengamuk jika } \\
\text { ada sesuatu yang ia } \\
\text { inginkan. Secara }\end{array}$ \\
\hline
\end{tabular}




\begin{tabular}{|c|c|c|c|}
\hline & & & $\begin{array}{l}\text { sosial, anak korban } \\
\text { lebih minder dari } \\
\text { teman-teman } \\
\text { sepermainannya } \\
\text { secara ekonomi, } \\
\text { kebutuhan anak } \\
\text { korban banyak tidak } \\
\text { terpenuhi }\end{array}$ \\
\hline 3 & Jurai dan UJ & $\begin{array}{l}\text { Tidak mau tau lagi } \\
\text { dengan anak dan } \\
\text { tidak pernah } \\
\text { memberi nafkah anak } \\
\text { pasca perceraian }\end{array}$ & $\begin{array}{l}\text { Psikis, anak korban } \\
\text { lebih banyak diam, } \\
\text { murung dan suka } \\
\text { ngamuk-ngamuk jika } \\
\text { ada sesuatu yang ia } \\
\text { inginkan s Secara } \\
\text { Sosial, anak korban } \\
\text { lebih minder dari } \\
\text { teman-teman } \\
\text { sepermainannya. } \\
\text { Secara Ekonomi, anak } \\
\text { korban kebutuhan } \\
\text { anak korban banyak } \\
\text { tidak terpenuhi } \\
\text { Secara Pendidikan } \\
\text {,anak-anak korban } \\
\text { kehilangan rak } \\
\text { pendidikanya } \\
\text { melakukan dan } \\
\text { pernikahan dini. }\end{array}$ \\
\hline 4 & Marni dan BS & $\begin{array}{l}\text { Tidak diketahui lagi } \\
\text { keberadaan pasca } \\
\text { perceraian, }\end{array}$ & $\begin{array}{l}\text { Secara psikis anak } \\
\text { menjadi pendiam dan } \\
\text { mider, secara ekonomi } \\
\text { anak putus sekolah, } \\
\text { Anak berprilaku } \\
\text { negatif suka mencuri }\end{array}$ \\
\hline
\end{tabular}

PENUTUP

Simpulan

Anak merupakan pihak yang paling dirugikan jika terjadi perceraian pada kedua orang tuanya. Apabila orang tua bercerai maka anak tidak mendapatkan hak haknya sebagai anak terutama pemberian nafkah karena tingkat kepatuhan ayah membayar nafkah anak pasca perceraian sangat rendah di Kota Bengkulu. 
Supremasi Hukum : Jurnal Penelitian Hukum

p-ISSN: 1693-766X ; e-ISSN: 2579-4663, Vol. 27, No. 2, Agustus 2018, 105-117

Meskipun ada putusan pengadilan yang memutuskan besaran biaya hadhanah (nafkah anak) , putusan pengadilan tersebut tidak dipatuhi oleh si ayah. Kalaupun dipatuhi, besarannya tidak sesuai dengan putusan pengadilan. Perceraian orang tua berdampak buruk terhadap perkembangan psikologis anak dimana anak menjadi sensitif, merasa rendah diri, menarik diri dari pergaulan teman sebaya. Sedangkan dampak perceraian secara ekonomi mengakibatkan tidak terpenuhinya kebutuhan dasar anak termasuk hak anak mendapatkan pendidikan.

\section{Saran}

Rendahnya kesadaran ayah memberikan nafkah anak pasca perceraian berakibat negatif untuk tumbuh kembang anak. Untuk itu perlu ada upaya dari lembaga penegak hukum khususnya Pengadilan Agama untuk tidak mudah menjatuhkan putusan mengabulkan perceraian sebelum mendapat jaminan si ayah membayar nafkah anak pasca perceraian.

\section{DAFTAR PUSTAKA}

Susanto, Anton F., 2015, Penelitian Hukum Transformatif Partisipatoris, Setara Press Malang.

Agusta, Ivanovich, 2003, Teknik Pengumpulan dan Analisis Data Kualitatif, Makalah disampaikan dalam pelatihan metode kualitatif di pusat Penelitian Sosial Ekonomi. Litbang Pertanian Bogor 27 Februari 2003

Anglisticum, Ardiana Mali. 2015, Parents Communication after Divorce and Its Impact on their Children Behavior, Journal (IJLLIS) p-ISSN: $1857-8179$ eISSN: 1857-8187 Volume 4 (11)

Badan Pusat Statistik,

https://www.bps.go.id/linkTableDinamis/view/id/893,

diunduh tanggal 13 Mei 2017

Choiri. A. 2015, Penjaminan Harta Ayah Terhadap Kelalaian Pembayaran Nafkah Anak Pasca Perceraian (Perlindungan Hukum Terhadap Anak Korban Perceraian Bagian 2), diakses tanggal 02 Juli 2018 dari https://badilag.mahkamahagung.go.id/artikel/publikasi/artikel/penjamina n-harta-ayah-terhadap-kelalaian-pembayaran-nafkah-anak-pascaperceraian-oleh-dr-h-a-choiri-sh-mh-28-10, 28 Oktober 2015.

Dewa, Didmus Dewa, 2016, The Plight of Children as Secondary Victims of Divorce in Gweru Zimbabwe: 2013 - 2016, International Journal of Advanced Science and Technology Vol.91 12 ISSN: 2005-4238 IJAST Copyright (c) 2016 SERSC

Betra Sarianti, Tingkat Kepatuhan Ayah Membayar Nafkah Anak Pasca Perceraian 
Supremasi Hukum : Jurnal Penelitian Hukum

p-ISSN: 1693-766X ; e-ISSN: 2579-4663, Vol. 27, No. 2, Agustus 2018, 105-117

Indrayani, Anisa, (2011) Pendidikan Anak Dalam Keluarga Sebagai Bentuk Perlindungan Anak Dalam Perspektif Al-Qur'an, Jurnal Musawa ISSN: 1412-3460 E-ISSN: 2503-4596, Vol.10 (2), Juli 2011 (Terakreditasi Mentri Riset, Teknologi dan Pendidikan Republik Indonesia Nomor 2/E/KPT/2015

Malik, Rusdi, 2009. Memahami Undang Undang Perkawinan, Jakarta: Penerbit : Universitas Trisakti.

Mardani, 2016, Hukum Keluarga Islam di Indonesia Prenamedia Group Jakarta

Marzuki, Peter Mahmud, 2005 Penelitian Hukum, Jakarta

Republika, 2017, Kasus Anak Korban Perceraian tinggi, diunduh 17-11-2017 dari https://www.republika.co.id/berita/koran/halaman-1/16/10/07/oeo5ft47kasus-anak-korban-perceraian-tinggi

Sarianti, Betra, (2015), Perlindungan Anak Berhadapan Dengan Hukum Diantara Harapan dan Hambatan, Jurnal Ilmiah Kutei ISSN 1412-9639 edisi 28 April.

Tektona, Rahmadi Indra, 2012, Kepastian Hukum Terhadap Perlindungan Hak Anak Korban Perceraian Jurnal Muwazah, 2502-5368 (Paper) ISSN 20858353 Vol. 4 (1)

Undang Undang Nomor 1 Tahun 1974 Tentang Perkawinan. 